\title{
KARAKTERISTIK BAHASA ARAB
}

PUJI LESTARI

WULANDARI

SEKOLAH TINGGI AGAMA ISLAM NEGERI ( STAIN )Sorong,Papua Barat, Indonesia Email : pujiiLstri14@gmail.com

\begin{abstract}
ABSTRAK
Bahasa arab merupakan bahasa salah satu bahasa mayor di dunia. Bahasa ini digunakan secara resmi oleh kurang lebih dari 20 negara. Dan karena ia merupakan bahasa kitab suci dan tuntunan agama umat islam sedunia,maka tentu saja ia merupakan bahasa yang paling besar signifikasinya bagi ratusan juta muslim sedunia,baik yang berkebangsaan Arab maupun bukan. Dan bahasa arab sendiri mempunyai beberapa karakteristik yang luas .
\end{abstract}

\section{PENDAHULUAN}

Bahasa arab mempunyai tempat yang sangat khas dalam budaya masyarakat. Bahasa arab adalah bahasa yang dikenal erat hubungannya dengan agama islam. Kedatangan islam sebagai ajaran agama di suatu lingkungan masyarakat yang kemudian dianut sebagai pedoman hidupnya menuntut para pemeluknya untuk memahami bahasa arab yang merupakan bahasa kitab suci ajaran islam yaitu Al-qur'an dan al-hadis Nabi Muhammad SAW. Oleh karenanya bahasa arab mempunyai karakteristik yang banyak dan bermacam. 


\section{DEFINISI BAHASA ARAB}

Bahasa adalah sistem lambang bunyi yang arbitrer, yang digunakan oleh anggota suatu masyarakat untuk bekerja sama, berinteraksi, dan mengidentifikasikan diri. Ibnu Manzhur dalam Lisan al-Arab, mendefinisikan bahasa dengan: aswat yu'abbir biha kull qaum 'an aghradhihim (berbagai bunyi yang digunakan masyarakat untuk mengungkapkan berbagai maksud atau tujuan mereka.

Bahasa arab memiliki struktur tata bahasa yang sangat unik, ia mampu mengungkapkan suatu masalah dengan sangat jelas dan dengan kata-kata yang sangat hemat, pembentukan frasa, kalimat, dan kata-katanya sangat teliti. Kata-katanya disusun berdasarkan konsep kata dasar, kata kerja biasa tersusun dari tiga atau empat konsonan huruf misalnya K-T-B (kataba, dia menulis), kata kerja dasar ini bisa ditashrif (diubah-ubah) sebagaimana kata kerja dalam bahasa lain, kata kerja ini juga bisa digunakan bersama sejumlah tenses, modus, dan infleksi yang tidak kita temukan dalam bahasa lainnya.

Kata dasar, etimologi, makna asli, serta kata jadian merupakan esensi bahasa arab, dengan semua itulah berbagai konsep, obyek, dan pemikiran dapat dilukiskan dengan kata-kata, katakata baru tidak harus dipinjam dari bahasa lain, bila para pakar pandai mencari kata-kata baru untuk memperkaya bahasa arab maka seluruh manusia akan mahir berbahasa arab. Dengan demikian bahasa arab sangat cocok untuk menjelaskan berbagai peraturan serta konsep, terutama karena bahasa arab tidak terpengaruh oleh berlalunya waktu, di sinilah pentingnya upaya pelestarian bahasa arab di tengah-tengah umat islam.

\section{CIRI KHAS BAHASA ARAB DAN KELEBIHANNYA}

Adapun beberapa ciri khas dari bahasa arab dan kelebihannya dari bahasa yang lain :

a. Jumlah huruf sebanyak 28 huruf dengan makharij al-huruf (tempat keluarnya huruf) yang tidak ada dalam bahasa lainnya. 
b. I'rab yakni sesuatu yang mewajibkan keberadaan akhir kata pada keadaan tertentu, baik itu rafa', nashab, jar, maupun jazm yang terdapat pada isim (kata benda), dan juga pada fi'il (kata kerja).

c. Ilmu 'arudi (ilmu notasi syi'ir) yang mana dengan ilmu ini menjadikan syi'ir berkembang dengan perkembangan sempurna.

d. Bahasa 'ammiyah dan fush-ha, bahasa 'ammiyah digunakan dalam berinteraksi jual beli atau berkomunikasi dalam situasi non formal, sedangkan bahasa fush-ha adalah bahasa sastra dan pembelajaran, serta bahasa resmi yang digunakan dalam percetakan.

e. Adanya huruf dhad yang tidak ada pada bahasa lainnya.

f. Kata kerja dan gramatikal yang digunakan selalu berubah sesuai dengan subjek yang yang menghubungkan dengan kata kerja tersebut.

g. Tidak adanya kata yang bersyakal dengan syakal yang sulit dibaca.

h. Tidak adanya kata yang mempertemukan dua huruf mati secara langsung.

i. Sedikit sekali kata-kata yang terdiri dari dua huruf (al-alfadz al-tsuna'iyyah), kebanyakan tiga huruf kemudian ketambahan lagi 1, 2, 3, atau 4 huruf.

j. $\quad$ Tidak adanya empat huruf yang berharakat secara terus menerus, di samping aspek-aspek lain yang termasuk dalam ranah deep structure (al-bina', al-dahily) baik segi fonologi, dan kamus.

\section{Karakteristik Universal Bahasa Arab}

Bahasa Arab memiliki karakteristik yang unik dan universal. Dikatakan unik karena bahasa Arab memiliki ciri khas yang membedakannya dengan bahasa lainnya, sedangkan universal berarti adanya kesamaan nilai antara bahasa Arab dengan bahasa lainnya. Karakteristik universalitas bahasa Arab antara lain dapat diuraikan sebagai berikut:

1. Bahasa Arab memiliki ragam bahasa, yang meliputi, 1) ragam sosial atau sosiolek yaitu 
ragam bahasa yang menunjukan stratifikasi sosial ekonomi penuturnya; 2) ragam geografis, ragam bahasa yang menunjukan letak geografis penutur antara satu daerah dengan daerah lain, sehingga melahirkan dialek yang beragam; 3) ragam idiolek yaitu ragam bahasa yang menunjukan integritas kepribadian setiap individu masyarakat (đa فنㅜ).

2. Bahasa Arab dapat diekspresikan secara lisan atau pun tulisan.

3. Bahasa Arab memiliki system, aturan dan perangkat yang tertentu, yang antara lain:

1. Sistemik, bahasa yang memiliki system standard yang terdiri dari sejumlah subsub system (sub sistem tata bunyi, tata kata, kalimat, sintax, gramatikal, wacana dan sebagainya).

2. Sistematis, artinya bahasa Arab juga memiliki aturan-aturan khusus, dimana masing-masing komponen sub sistem bahasa bekerja secara sinergis dan sesuai dengan fungsinya.

3. Komplit, maksudnya bahasa itu memiliki semua perangkat yang dibutuhkan oleh masyarakat pemakai bahasa itu ketika digunakan untuk sebagai alat komunikasi dalam berinteraksi dan bersosialisasi antar mereka.

4. Bahasa Arab memiliki sifat yang arbitrer dan simbolis. Arbitrer berarti mana suka, artinya tidak adanya hubungan rasional antara lambang verbal dengan acuannya. Dengan sifat simbolis yang dimiliki bahasa, manusia dapat mengabstraksikan berbagai pengalaman dan buah pikirannya tentang berbagai hal.

5. Bahasa Arab berpotensi untuk berkembang, produktif dan kreatif. Karena perkembangan bahasa selalu mengikuti perkembangan peradaban manusia, sehingga muncul kata dan istilah-istilah bahasa baru yang digunakan untuk mengkomunikasikan ilmu pengetahuan dan teknologi yang terus berkembang.

6. Bahasa Arab merupakan fenomena individu dan fenomena sosial. Sebagai fenomena individu, bahasa merupakan ciri khas kemanuisaan. Ia bersifat insani karena hanya manusia yang mempunyai kemampuan berbahasa verbal. Adapun sebagai fenomena sosial, bahasa merupakan konvensi suatu masyarakat pemilik atau pemakai bahasa itu. 
Seseorang menggunakan bahasa sesuai norma-norma yang disepakati atau ditetapkan untuk bahasa tersebut. Kesepakatan yang dimaksudkan pada dasarnya merupakan kebiasaan yang berlangsung turun temurun dari nenek moyang, yang sifatnya mengikat dan harus diikuti oleh semua pengguna bahasa.

7. Bahasa pada hakekatnya adanya bunyi, yaitu berupa gelombang udara yang keluar dari paru-paru melalui pipa suara dan melintasi organ-organ speech atau alat bunyi. Bahasa Arab, sebagai salah satu rumpun bahasa Semit, memiliki ciri-ciri khusus dalam aspek bunyi yang tidak dimiliki bahasa lain, terutama bila dibandingkan dengan bahasa Indonesia atau bahasa-bhasa daerah yang banyak digunakan di seluruh pelosok tanah air Indonesia. Ciri-ciri khusus itu adalah:

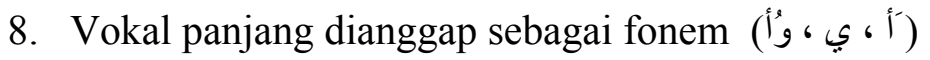

9. Bunyi tenggorokan (قلحا تاوصLا), yaitu $ح$ dan $ع$

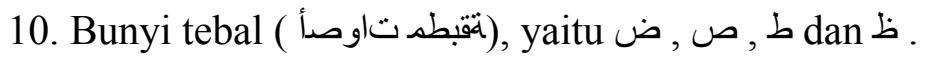

11. Tekanan bunyi dalam kata atau stress (ربنال)

12. Bunyi bilabial dental (كنانسأ قوفوش), yaitu ف

13. Ciri khas kedua yang dimiliki bahasa Arab adalah pola pembentukan kata yang sangat fleksibel, baik melalui derivasi (كقاقتسا فيرصت) maupun dengan cara infleksi (فيرصت) ( ) ( ) Dengan melalui dua cara pembentukan kata ini, bahasa Arab menjadi sangat kaya sekali dengan kosakata. Misalnya dari akar kata cara sقاقتشا, maka akan menjadi :

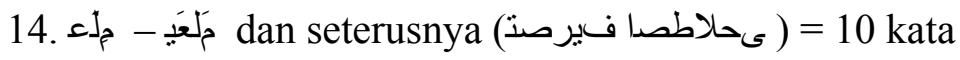

\section{KESIMPULAN}


1. Bahasa adalah sistem lambang bunyi yang arbitrer, yang digunakan oleh anggota suatu masyarakat untuk bekerja sama, berinteraksi, dan mengidentifikasikan diri.

Bahasa arab memiliki struktur tata bahasa yang sangat unik, ia mampu mengungkapkan suatu masalah dengan sangat jelas dan dengan kata-kata yang sangat hemat, pembentukan frasa, kalimat, dan kata-katanya sangat teliti.

2. Bahasa arab sendiri mempunyai ciri khas yaitu jumlah huruf sebanyak 28 dengan makharij al huruf (tempat keluarnya huruf) yang tidak ada dalam bahasa lainnya. Dan bahasa mempunyai I'rab sesuatu yang mewajibkan keberadaan akhir kata pada keadaan tertentu.

3. Bahasa Arab memiliki karakteristik yang unik dan universal. Dikatakan unik karena bahasa Arab memiliki ciri khas yang membedakannya dengan bahasa lainnya, sedangkan universal berarti adanya kesamaan nilai antara bahasa Arab dengan bahasa lainnya. 


\section{DAFTAR PUSTAKA}

Azhar Arsyad.(2003).Bahasa Arab dan Metode Pengajarannya, Yogyakarta: PUSTAKA BELAJAR

Sukron Kamil.(2009).Teori Kritik Sastra Arab,Klasik dan Modern, Jakarta : Rajawali Pers

Azhar Arsyad.(2011).Dasar-Dasar Penguasaan Bahasa Arab,Yogyakarta : PUSTAKA

BELAJAR

Ahmad Izzan.(2011).Metedologi Pembelajaran Bahasa Arab,Bandung : Humaniora

Muhammad Thalib.(2009).Sistem Cepat Belajar Bahasa Arab, Yogyakarta : Media Hidayah 